\title{
Multifunctional Epoxy/Nanocomposites Based on Natural Moroccan Clays with High Antimicrobial Activity: Morphological, Thermal and Mechanical Properties
}

\author{
M. Monsif, ${ }^{1,2}$ A. Zerouale, ${ }^{1}$ N. Idrissi Kandri, ${ }^{2}$ R. Bertani $\left({ }^{3},{ }^{3}\right.$ A. Bartolozzi, ${ }^{3}$ B. M. Bresolin, ${ }^{3}$ \\ F. Zorzi, ${ }^{4}$ F. Tateo, ${ }^{5}$ M. Zappalorto ${ }^{1 D},{ }^{6}$ M. Quaresimin, ${ }^{6}$ and P. Sgarbossa ${ }^{3}{ }^{3}$ \\ ${ }^{1}$ Laboratory of Chemistry of Condensed Matter, Faculty of Sciences and Technology, University Sidi Mohamed Ben Abdellah, \\ Road Imouzzer, B.P. 2202 Atlas Fes, Morocco \\ ${ }^{2}$ Laboratory of Applied Chemistry, Faculty of Sciences and Technology, University Sidi Mohamed Ben Abdellah, Road Imouzzer, \\ B.P. 2202 Atlas Fes, Morocco \\ ${ }^{3}$ Department of Industrial Engineering, University of Padova, Via F. Marzolo 9, Padova, Italy \\ ${ }^{4}$ Department of Geosciences, University of Padova, via Gradenigo 6, 35131 Padova, Italy \\ ${ }^{5}$ C.N.R. Institute of Geosciences and Earth Resources, via Gradenigo 6, 35131 Padova, Italy \\ ${ }^{6}$ Department of Management and Engineering, University of Padova, Stradella San Nicola 3, 36100 Vicenza, Italy
}

Correspondence should be addressed to R. Bertani; roberta.bertani@unipd.it and M. Zappalorto; zappalorto@gest.unipd.it

Received 25 March 2019; Revised 30 July 2019; Accepted 3 September 2019; Published 22 November 2019

Academic Editor: Domenico Acierno

Copyright (c) 2019 M. Monsif et al. This is an open access article distributed under the Creative Commons Attribution License, which permits unrestricted use, distribution, and reproduction in any medium, provided the original work is properly cited.

\begin{abstract}
In this study, a series of new epoxy/clay nanocomposites (ECN) has been prepared and characterized in order to investigate the properties and compare the effect of the unmodified Moroccan clay on the structure and properties of the composite materials. Five natural clays have been used to reinforce the neat epoxy resin with $1 \%$ wt and $5 \%$ wt achieving the clay dispersion only through strong milling and mechanical stirring without previous organic modifications of the clays. The quality of clay dispersion in the epoxy matrix and the morphology of nanocomposites have been studied by transmission electron microscopy (TEM), environmental scanning electron microscopy (ESEM), and X-ray diffraction (XRD). The mechanical and thermal properties have also been investigated. The antimicrobial activity of the nanocomposites has been tested against E. coli and S. aureus in order to evaluate their applicability as advanced antimicrobial materials. The results showed that the epoxy/crude clay nanocomposites exhibited a high inhibition action attending $99 \%$ against both bacteria in the case of the clay labeled $A 5$.
\end{abstract}

\section{Introduction}

In recent years, one of the most intriguing topics concerning polymer nanocomposites is the design and preparation of materials exhibiting improved and/or new properties for a variety of applications [1]. There has been enormous interest from industries for the manufacturing and commercialization of nanocomposites for applications in aerospace [2], automotive [3], packaging $[4,5]$, electronics [6], and other industrial sectors $[7,8]$. These materials also showed a potential use as solution for energy and environmental issues
[9]. Nanocomposites are materials based on the combination of a selected matrix and nanodimensional phases. Thus, different materials have been used for their preparation. Among them, polymer nanocomposites containing inorganic nanoscale particles homogeneously dispersed into selected polymer matrices have been extensively investigated and used [10]. The typical nanofiller is clay, but graphite, singleand multiple-wall nanotubes, nanoscale silica [11], and titania [12] have also been investigated. Epoxy resins, extensively used in a wide variety of industrial applications, exhibit weak mechanical properties, thus requiring support through 
TABLE 1: Mineralogical, chemical composition, and physical properties of the clay samples.

\begin{tabular}{|c|c|c|c|c|c|}
\hline $\begin{array}{l}\text { Mineralogical } \\
\text { composition }\end{array}$ & $\begin{array}{c}\text { A1 } \\
\text { Qz, Kaol, } \\
\text { Chl, Il/Musc, } \\
\text { Il/Sm, Py, Cal }\end{array}$ & $\begin{array}{c}\text { A2 } \\
\text { Qz, Kaol, } \\
\text { Chl, Il/Musc, } \\
\text { Il/Sm, Py, Cal }\end{array}$ & $\begin{array}{c}\text { A3 } \\
\text { Qz, Kaol, } \\
\text { Chl, Il/Musc, } \\
\text { Py, Cal }\end{array}$ & $\begin{array}{c}\text { A4 } \\
\text { Qz, Kaol, } \\
\text { Musc, Il, } \\
\text { Feld, Cal, Dol }\end{array}$ & $\begin{array}{c}A 5 \\
\text { Qz, Kaol, } \\
\text { Il, } \\
\text { Goe }\end{array}$ \\
\hline \multicolumn{6}{|c|}{ Chemical composition (\% wt) } \\
\hline $\mathrm{SiO}_{2}$ & 54.50 & 53.60 & 53.60 & 42.60 & 62.70 \\
\hline $\mathrm{TiO}_{2}$ & 0.85 & 0.84 & 0.87 & 0.44 & 0.79 \\
\hline $\mathrm{Al}_{2} \mathrm{O}_{3}$ & 27.4 & 26.5 & 26.00 & 11.00 & 21.30 \\
\hline $\mathrm{Fe}_{2} \mathrm{O}_{3}$ & 4.89 & 5.61 & 5.95 & 2.32 & 4.95 \\
\hline $\mathrm{MnO}$ & 0.07 & 0.13 & 0.12 & 0.04 & 0.11 \\
\hline $\mathrm{MgO}$ & 1.76 & 2.05 & 2.19 & 3.29 & 0.84 \\
\hline $\mathrm{CaO}$ & 0.31 & 0.69 & 1.02 & 18.80 & 0.33 \\
\hline $\mathrm{Na}_{2} \mathrm{O}$ & 1.24 & 1.50 & 1.68 & 0.82 & 0.87 \\
\hline $\mathrm{K}_{2} \mathrm{O}$ & 1.92 & 2.10 & 2.06 & 1.30 & 1.67 \\
\hline $\mathrm{P}_{2} \mathrm{O}_{5}$ & 0.23 & 0.18 & 0.17 & 0.24 & 0.06 \\
\hline L.O.I. & 6.65 & 6.58 & 6.15 & 18.70 & 6.12 \\
\hline
\end{tabular}

Qz: quartz; Chl: chlorite; Il/Musc: illite/muscovite; Kaol: kaolinite; Py: pyrophyllite; Fld: feldspars; Cal: calcite; Dol: dolomite; Goe: goethite; Il/Sm: illite/smectite.

nanoscale blending with other synthetic polymers, fibers, or inorganic materials [13]. However, the improvement of epoxy/clay nanocomposite (ECN) properties depends not only on the concentration of clay but also on its dispersion quality and adhesion in the polymer matrix [14]. Only a few hydrophilic polymers such as poly(ethylene oxide) and poly(vinyl alcohol) can be miscible with clay nanolayers [15]. Therefore, clays are usually organically modified with cationic-organic surfactants [16] in order to make them compatible with organic polymers and to improve their dispersion into the matrix. Clays can be intercalated with several organic and inorganic species $[17,18]$ including ethylenediamine [19], ammonium [20], or phosphonium ions [21, 22]. Other authors studied different dispersion methods using an ultrasonic mixing procedure or mechanical blending [23-25]. The dispersion of a sufficient quantity of nanoclays can significantly improve the mechanical properties of the material compared to those of the neat epoxy polymers in pristine form [26-28] and increase heat resistance achieving a combination of new optical, electrical, thermal, and biological properties [29].

Inorganic materials with antibacterial properties attracted significant attention for application in biomedical devices or in antimicrobial packaging and items in daily use [30]. Therefore, the preparation of epoxy/clay nanocomposites with antimicrobial activity can be of interest [31, 32]. Recently, the antibacterial activity of polymer nanocomposites with different fillers has been studied. For instance, the addition of Na-montmorillonite in some composites, such as chitosan/P$\mathrm{VOH}$ films, resulted in $40 \%$ growth inhibition of E.coli [33] while epoxy resin nanocomposites with copper-modified clays exhibited antibacterial activity against both Gram-negative and Gram-positive bacteria [34-36]. In general, this activity was found in nanocomposites containing modified clays with cationic systems [37] or metal ions such as copper [35] and silver [38, 39].
To our knowledge, even if it was reported that some raw clays have bactericidal activity against both Gram-positive and Gram-negative bacteria [40-44], and against antibioticsusceptible and antibiotic-resistant bacterial pathogens [45], no publications on the antibacterial activity of epoxy/clay nanocomposites with unmodified clay have been reported.

In this study, new epoxy/clay nanocomposites containing $1 \%$ wt and $5 \%$ wt of natural clay with a sufficient dispersion were prepared, although in the absence of organic modifications and only through strong milling and mechanical stirring.

The mechanical and thermal properties of the composites together with the antibacterial activity have been studied in order to evaluate their applicability as advanced antimicrobial materials.

\section{Material and Methods}

This section is aimed at describing the materials used in the experimental program, their preparation, and the methods used for the characterization of their mechanical and antimicrobial properties, which were carried out following the methods used in Ref. [35], where the antibacterial activity of multifunctional $\mathrm{Cu}^{2+}$-montmorillonite/epoxy resin nanocomposites was studied.

2.1. Materials. With the aim of the valorization of some local raw materials from Morocco, five clay materials noted as $A 1$, $A 2, A 3, A 4$, and $A 5$ from different regions and with different compositions were collected to be used as filler in the preparation of epoxy nanocomposites. Before their use, the clays were dried at $60^{\circ} \mathrm{C}$, crushed and sieved at $80 \mu \mathrm{m}$, and characterized by different techniques [46]. The data concerning the chemical composition are reported in Table 1. A diglycidyl ether of bisphenol A epoxide (DGEBA, Elan-tech EC157) and the mixture of cycloaliphatic amines (Elan-tech 
W 152LR), both supplied by Elantas, have been used as polymer precursors.

2.2. Preparation of Epoxy/Clay Nanocomposites. The nanocomposites using the sieved fraction were prepared through mechanical dispersion by mixing the epoxy resin with the unmodified clays. Specifically, epoxy formulations containing 1 and $5 \%$ by weight of clay were considered. Initially, a measured amount of unmodified $80 \mu \mathrm{m}$ sieved clays $(A 1$, $A 2, A 3, A 4$, and $A 5$ ) was added to the diglycidyl ether of bisphenol A epoxy in a flask. The dispersion process was performed at room temperature under constant magnetic stirring $(900 \mathrm{rt} / \mathrm{min})$ for about $18 \mathrm{hrs}$ until the dispersion was homogeneous. Then, the curing agent (the mixture of cycloaliphatic amines) was added under magnetic stirring according to the stoichiometric ratio from the supplier's datasheet $(3: 1=$ epoxide/amine wt/wt). The reacting mixture was degassed for $20 \mathrm{~min}$ after the addition of the hardener to remove the air trapped within the blend. Finally, the obtained mixture was casted onto open silicon molds to be cured at room temperature for 24 hours and then in an oven at $60^{\circ} \mathrm{C}$ for 6 hours. The samples of epoxy clay nanocomposite have been identified as $\mathrm{EC}_{\mathrm{P}}$, where $\mathrm{E}$ was the epoxy, $\mathrm{C}$ referred to the clay, and $\mathrm{P}$ was the percentage of used clay.

\subsection{Characterization and Mechanical Properties of the Nanocomposites}

2.3.1. Fourier Transform Infrared Spectroscopy. FTIR spectra of the clay powders were obtained on a Nicolet Avatar 320 spectrophotometer as $\mathrm{KBr}$ pellets. For each sample, 32 scans were recorded in the range $4000-400 \mathrm{~cm}^{-1}$ in the transmittance mode with a resolution of $4 \mathrm{~cm}^{-1}$. ATR-FTIR spectra on the polymeric materials were collected with a Nicolet Nexus 5700 instrument at $23^{\circ} \mathrm{C}$ and $35-45 \%$ RH (10 reflections, ZnSe crystal).

2.3.2. X-Ray Diffraction. Powder and nanocomposite XRD analyses were carried out with a PANalytical X'Pert Pro diffractometer equipped with a Co X-ray tube (operating at $40 \mathrm{kV}$ and $40 \mathrm{~mA}$ ) and a real-time multiple strip (RTMS) detector (X'Celerator). The diffraction profiles were collected over the $2 \theta$ range of $2.6-85^{\circ}$, with a virtual $2 \theta$ step size of $0.017^{\circ}$ and a counting time of $100 \mathrm{~s} / \mathrm{step}$.

2.3.3. Environmental Scanning Electron Microscopy. The microanalysis and morphology of the samples have been studied by ESEM (Quanta 200 FEI-XRF embedded). The samples have been observed directly on cross sections obtained by brittle fracture at the temperature of liquid nitrogen.

2.3.4. Transmission Electron Microscopy. The morphology of the nanocomposites was studied by transmission electron microscopy (TEM) with a JEM 2000 EX-II (Jeol, Japan) microscope, at $120 \mathrm{kV}$. $120 \mathrm{~nm}$ thick films were obtained by cutting the samples with a PT-PC Power Tome ultramicrotome at room temperature (RMC Boeckeler Instruments, USA).
2.3.5. Mechanical Properties. Tensile tests on dog-bone (DB) specimens were carried out taking advantage of a MTS809 servo-hydraulic machine equipped with a $2.5 \mathrm{kN}$ load cell using a crosshead speed equal to $2 \mathrm{~mm} / \mathrm{min}$ and with a MTS 632.29F-30 extensometer. The specimen geometry was chosen according to the ISO 527-2 suggestions [47]. Five specimens were tested for each clay content in order to obtain statistical representative results. In all cases, failure took place in the gauge length of the specimens. Fracture tests were carried out on compact tension (CT) specimens of which the geometry and size comply with ASTM D5045-99 suggestions [48]. According to previously reported procedures [49-51], after demoulding, specimens were precracked by manual tapping, obtaining artificial short cracks. Then $10 \mathrm{~mm}$ long cracks were obtained by loading the tapped samples with some zero-to-tension fatigue cycles. For each composite, five specimens were tested. Experimental results were rearranged, and for each test, the value of $K_{\text {IC }}$ was determined starting from the crack length and the fracture load, according to ASTM D5045 [48].

2.3.6. Thermogravimetric Analysis. TGA were performed on a TGAQ 5000 thermogravimetric analyser, TA Instruments, under air atmosphere: $15-20 \mathrm{mg}$ of the samples were heated from $25^{\circ} \mathrm{C}$ to $900^{\circ} \mathrm{C}$ under air atmosphere with a heating rate of $10^{\circ} \mathrm{C} / \mathrm{min}$.

2.3.7. Zero Surface Charge Determination. By using the solid addition method [52], the zero surface charge characteristics of the epoxy/clay nanocomposites were determined. In a series of $50 \mathrm{ml}$ of $0.1 \mathrm{M} \mathrm{KNO}_{3}$ solution, the $\mathrm{pH}_{0}$ values were adjusted to $2,4,6,8$, and 10 by adding either $0.1 \mathrm{M} \mathrm{HCl}$ or $0.1 \mathrm{M} \mathrm{NaOH}$. Then, one gram of crushed specimens was added to each flask. The suspensions were then manually shaken and allowed to equilibrate for $48 \mathrm{~h}$ with intermittent manual shaking. The final $\mathrm{pH}$ values of the supernatant liquid were noted. The difference between the initial $\mathrm{pH}\left(\mathrm{pH}_{0}\right)$ and the final one $\left(\mathrm{pH}_{\mathrm{f}}\right)$ values $\left(\mathrm{pH}=\mathrm{pH}_{0}-\mathrm{pH}_{\mathrm{f}}\right)$ was plotted against the $\mathrm{pH}_{0}$. The point of intersection of the resulting curve with abscissa, at which $\mathrm{pH}=0$, gave the $\mathrm{pH}_{\mathrm{pzc}}$.

\subsection{Antimicrobial Activity}

2.4.1. Antimicrobial Activity of the Raw Clays. The antimicrobial activity of clays has been determined against Escherichia coli (E. coli) TCC 8739 and Staphylococcus aureus (S. aureus) ATCC 6538P, selected as examples of Gram-negative and Gram-positive bacteria as recommended by ISO 22196 [53] following the procedure previously reported [35]. Both bacteria were cultured overnight at $35^{\circ} \mathrm{C}$ onto Tryptic Soy Agar (TSA) before use and diluted in Nutrient Broth (NB) 1:500 with distilled water in order to obtain suspensions containing $10^{5}-10^{8}$ cells $/ \mathrm{ml}$, suitable for the experiments. Sterilized clays $(1 \mathrm{~g})$ were introduced into $800 \mu \mathrm{l}$ of NB containing the initial pathogen inoculum, and the mixtures were incubated at $35^{\circ} \mathrm{C}$ for $24 \mathrm{~h}$. Positive controls for growth of bacteria in the absence of clays were carried out together with each series of experiments. In addition, negative controls were performed in order to ensure that the clay samples maintained sterilization during storage. After incubation, the mixtures 
were subjected to successive 10 -fold dilutions in distilled sterilized water and quantitatively cultured in duplicate onto TSA plates to determine the number of viable bacteria. Viable cell counts are expressed as $\log _{10}$ cfu per $800 \mu \mathrm{l}$.

2.4.2. Antibacterial Activity of the Nanocomposites. The surface biocidal capacity of the nanocomposites has been evaluated against E. coli ATCC 8739 and S. aureus ATCC $6538 \mathrm{P}$ according to ISO 22196 and OECD guidelines [53, 54] and following the procedure previously described [35]. Each strain microbial testing was performed in triplicate: 6 specimens of neat epoxy resins were used as control (3 for $t$ $=0$ and 3 for $t=24$ hours) and 3 samples of each nanocomposite were tested. The samples were treated with a sterilizing UV irradiation, then an area of $4 \mathrm{~cm}^{2}$ was coated with $50 \mu \mathrm{l}$ $\left(12.5 \mu \mathrm{l} / \mathrm{cm}^{2}\right)$ of suspension of diluted bacteria in NB containing $10^{5}-10^{7}$ cells and incubated for $24 \mathrm{hrs}$ at $35^{\circ} \mathrm{C}$. The bacteria were recovered by adding $10 \mathrm{ml}$ of soybean casein digest with lecithin and polysorbate neutralizer broth (SCDLP) and 10-fold serial diluted in phosphate-buffered physiological saline solution. Then, $1 \mathrm{ml}$ of each dilution was put into Petri dishes with $15 \mathrm{ml}$ of Molten Plate Count Agar (PCA) and incubated at $35^{\circ} \mathrm{C}$ for $40 \mathrm{hrs}$ (all the platings were performed in duplicate). Results were expressed as the number of units forming colonies (cfu) per $\mathrm{cm}^{2}$, and the percentage of inhibition was calculated with the equation established in the standard test method ASTM E2149-01 [55] comparing data with reference samples.

\section{Results and Discussion}

3.1. Natural Clay Characterization. The fractions below 80 $\mu \mathrm{m}$ of unmodified clays used as raw material have been firstly characterized to obtain an overview of their characteristics and properties [46]. The results, collected in Table 1, revealed their mineralogical and chemical composition. All the samples contained quartz, kaolinite, micas (mainly illite and/or muscovite), and expansible minerals (such as mixed layers, smectite, or vermiculite) associated with other clays and nonclay minerals. For $A 1, A 2$, and $A 3$, chlorite, pyrophyllite, and calcite were also present; $A 4$ contained feldspars, calcite, and dolomite while $A 5$ had goethite. The chemical compositions of the five Moroccan clays showed that the powders had a high content of silica due to the presence of quartz and other silicates, together with alumina. $\mathrm{K}_{2} \mathrm{O}, \mathrm{MgO}$, and $\mathrm{Na}_{2} \mathrm{O}$ were present in small quantities, and their amounts were associated with the occurrence of illite, chlorite, feldspars, and mixed layers in agreement with the mineralogical composition. Iron can be incorporated into clays minerals as oxides and hydroxides, as observed for $A 1, A 2, A 3$, and $A 5$. Only $A 4$ contained an important amount of $\mathrm{CaO}(18.80 \% \mathrm{wt})$ and the highest content of $\mathrm{MgO}$, according to the occurrence of calcite and dolomite. A5 was characterized by the highest content of $\mathrm{SiO}_{2}(62.70 \% \mathrm{wt})$ and the lowest amount of $\mathrm{MgO}$, which explained the high quartz content and the absence of chlorite. It should be noted that $A 1$ and $A 4$ have been recently used to prepare geopolymers [56].

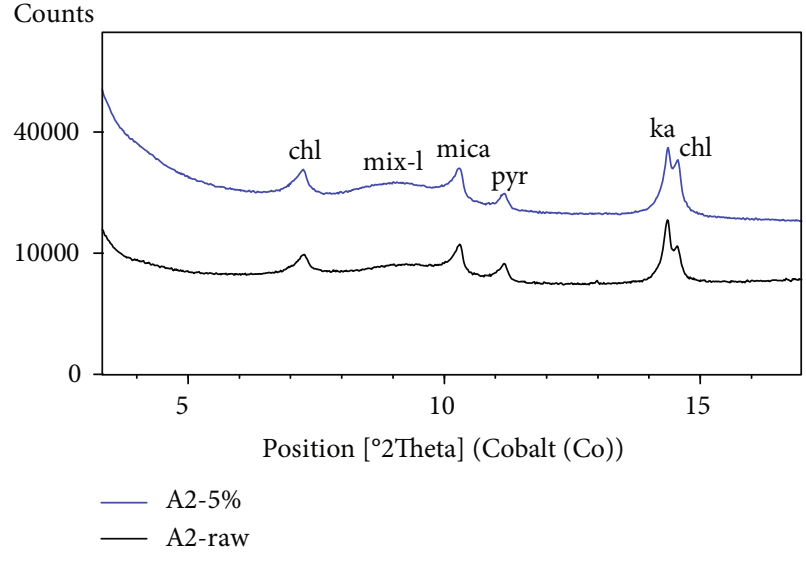

Counts

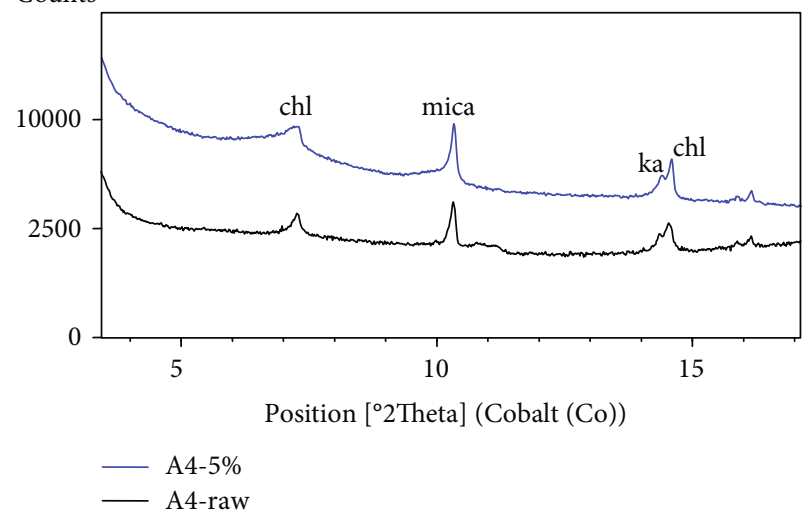

FIgURE 1: XRD spectra of clays $A 2$ and $A 4$ and of the corresponding nanocomposites $E A 2_{5 \%}$ and $E A 4_{5 \%}$. chl: chlorite; mica: illite and/or muscovite; pyr: pyrophyllite; ka: kaolinite; mix-l: mixed layers.

3.2. Epoxy/Clay Nanocomposite Characterization. A few publications described the preparation of epoxy/clay nanocomposites with the incorporation of unmodified clay [57] or minerals [58]. Herein, we studied the dispersion of some natural clays in the absence of organic modification within the epoxy resin matrix and described the chemical and physical characterization of the nanocomposites.

The FTIR spectra (Figure SI.1) resulted in being slightly modified with respect to the spectrum of the pristine epoxy resin (the strong absorptions of $v_{\text {CCaromatic }}, v_{\mathrm{CCOC}}, v_{\mathrm{CN}}$, and $v_{\mathrm{COC}}$ ethers and $v_{\mathrm{COC}}$ oxirane were present at 1508 , $1239,1104,1032$, and $827 \mathrm{~cm}^{-1}$, respectively) along with an increased broad band at $3392 \mathrm{~cm}^{-1}$ of the $\mathrm{OH}$ stretching of $\mathrm{Si}-\mathrm{OH}$ and $\mathrm{Al}-\mathrm{OH}$ and of the hydroxyl groups present in the epoxy matrix $[35,36]$. Only in the case of EA4 was a broadening of the signal at $1450 \mathrm{~cm}^{-1}$ observed due to the presence of a strong and broad signal in $A 4$ at $1430 \mathrm{~cm}^{-1}$ of calcite.

In Figure 1, selected XRD spectra (Figure SI.2) of the nanocomposites have been reported. The spectra exhibited the signals corresponding to the crystalline phases of the original clay. No clear evidence of the presence of intercalated systems could be observed, reasonably due to the use of raw clays, without previous pretreatment with organic components. 


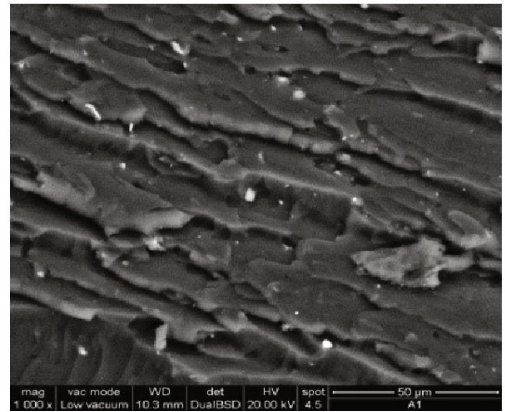

$\mathrm{EAl}_{5 \%}$

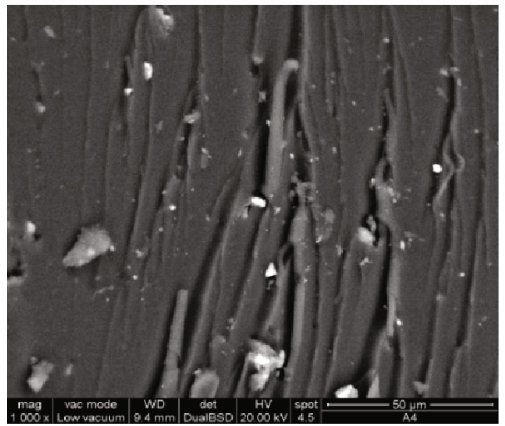

$\mathrm{EA}_{5 \%}$

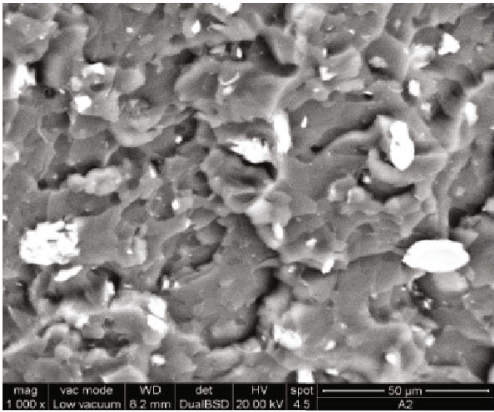

$\mathrm{EA} 2_{5 \%}$

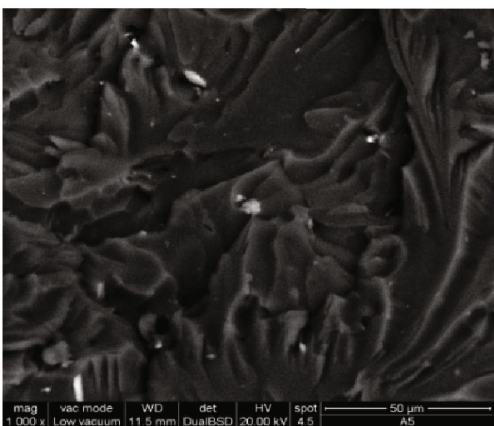

$\mathrm{EA}_{5 \%}$

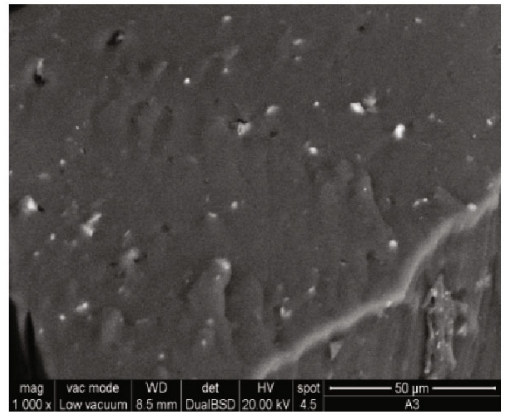

$\mathrm{EA}_{5 \%}$

FIGURE 2: ESEM images of the fracture surfaces of epoxy/clay nanocomposite specimens with $5 \%$ wt clay content (scale bar $50 \mu \mathrm{m}$ ).

ESEM analyses of the fracture surfaces (Figure 2) revealed a homogeneous distribution of the clay in all epoxy resin nanocomposites even with $5 \%$ wt of clay content with some agglomeration of the particles, which were distributed along the brittle fracture surface up to a size of few microns, particularly in the EA2 and EA4 samples. Micrographs showed the silicate layer penetration in between the epoxy network, as well as the different paths of the crack, particularly for EA3 where the higher amount of phyllosilicates [46] could lead to a better intercalation in the composite. The clay particles reasonably acted as obstacles causing the crack. Liu et al. [59] reported that more than one toughening mechanism usually occurs in the epoxy/clay system such as shear yielding of the matrix, crack deflection (evidenced in the EA1,EA2, EA4, and EA5 samples), micro voiding, and debonding between the clay and epoxy (as observed for EA3) [60].

TEM analyses (Figure 3) showed some exfoliated and intercalated structures (in particular for the samples bearing $5 \%$ of clay) together with a bigger stack of platelets dispersed inside the epoxy matrix. Composite $E A 3_{5 \%}$ displays the smallest clay agglomerates with exfoliated fragments compared with the other samples, in agreement with the suggested effect of the higher phyllosilicate content on the intercalation.

3.3. Thermal Stability of the Nanocomposites. In Figure 4, the thermograms of the nanocomposites have been shown, and in Table 2, the onset temperature of thermal degradation and the percentage of residue after thermal degradation have been reported. It could be observed that the incorporation of unmodified clays decreased to some degrees (from $319^{\circ} \mathrm{C}$ to about $315^{\circ} \mathrm{C}$ ) the thermal degradation onset in the presence of $1 \%$ of clay and about one degree more in the presence of $5 \%$ wt for $A 1-A 4$. In the case of $A 5$, an increase up to $325^{\circ} \mathrm{C}$ was observed for $1 \%$ of clay, but a decrease to $310^{\circ} \mathrm{C}$ for $5 \%$. This behavior could be in principle explained by the low level of intercalation within the nanocomposite and by a catalytic effect on the thermal degradation of the epoxy matrix of the metal oxides (in particular iron oxide) in the clays [61].

3.4. Mechanical Properties of the Nanocomposites. The effect of the weight content of nanoclay on the nanocomposite strain to failure $\left(\varepsilon_{R}\right)$, tensile strength $\left(\sigma_{R}\right)$, and Young's modulus $(E)$ is shown in Figure 5. In particular, it was evident from Figure 5(a) that the addition of $1 \%$ wt of nanoclays to the epoxy resin always resulted in an increase of the strain to failure. Such an increase was limited, in the case of $A 2$ and $A 3$, whereas it was pronounced for $A 1, A 4$, and $A 5$. A reverse trend could be noted, instead, in the case of $5 \%$ wt clay nanocomposites, which exhibited a strain to failure almost equal or lower than that of the neat polymer. Similar to the results for the strain to failure, as reported in Figure 5(b), the incorporation of a low amount of unmodified clay ( $1 \% \mathrm{wt}$ ) allowed the tensile strength $\sigma_{R}$ to be considerably improved (from 59.99 to $68.77,67.60$, 70.51, and $76.10 \mathrm{MPa}$ in the case of $E A 1_{1 \%}, E A 2_{1 \%}, E A 4_{1 \%}$, and $E A 5_{1 \%}$, respectively, when compared to neat epoxy resin). The increase of the weight content (from $1 \%$ to $5 \% \mathrm{wt}$ ) gave a decrease of $\sigma_{R}$ for $A 1, A 2$, and $A 3$, whilst nanocomposites $E A 4_{5 \%}$ and $E A 5_{5 \%}$ still preserved an enhanced tensile strength. The decrease of the tensile properties while increasing the clay loading (5\%) was in agreement with the results previously reported for epoxy resins in the literature $[35$, 


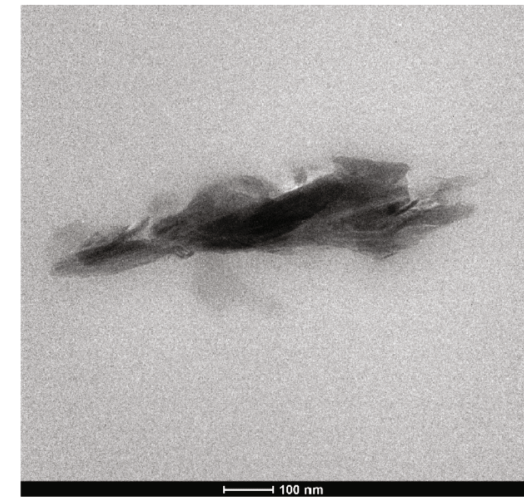

$\mathrm{EA}_{1 \%}$

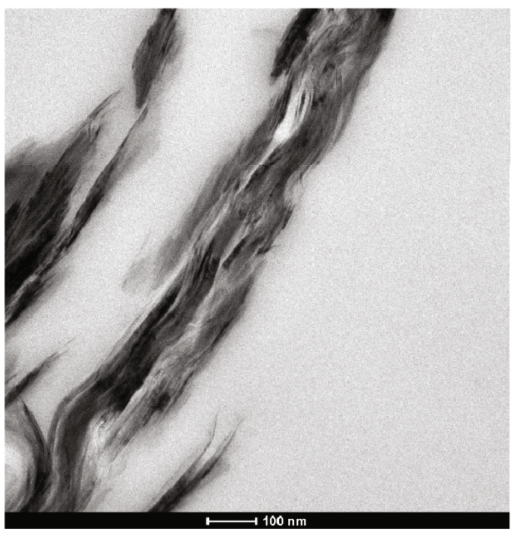

$\mathrm{EAl}_{5 \%}$

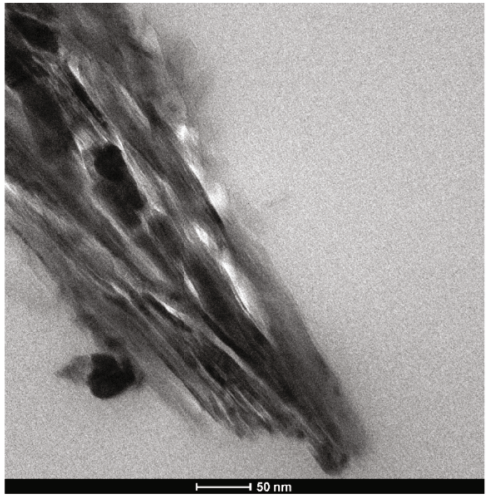

$\mathrm{EA} 2{ }_{1 \%}$

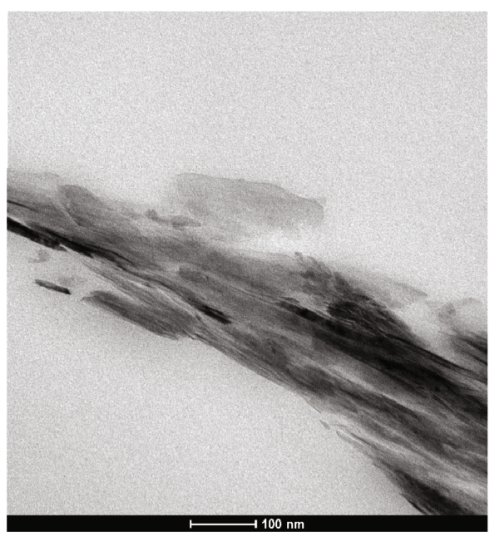

$\mathrm{EA} 2_{5 \%}$

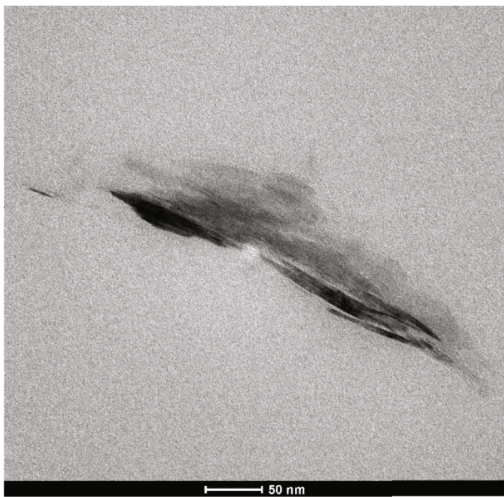

$\mathrm{EA}_{5 \%}$

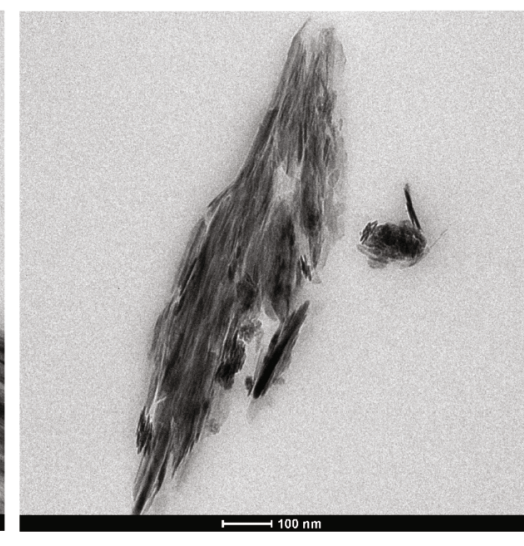

$\mathrm{EA}_{5 \%}$

FIGURE 3: TEM images of selected nanocomposites containing $1 \% \mathrm{wt}$ and $5 \% \mathrm{wt}$ of clay loading.

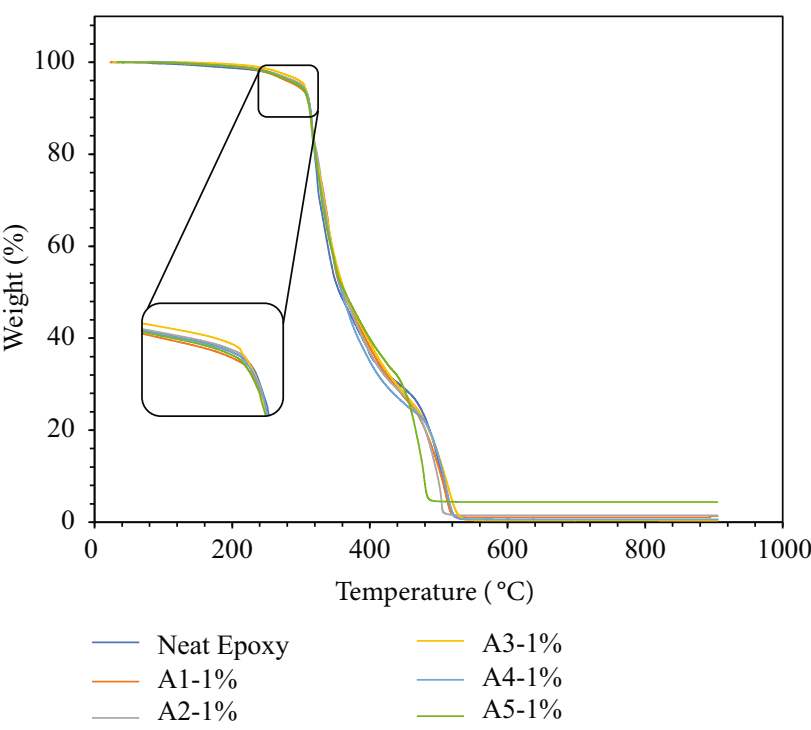

(a)

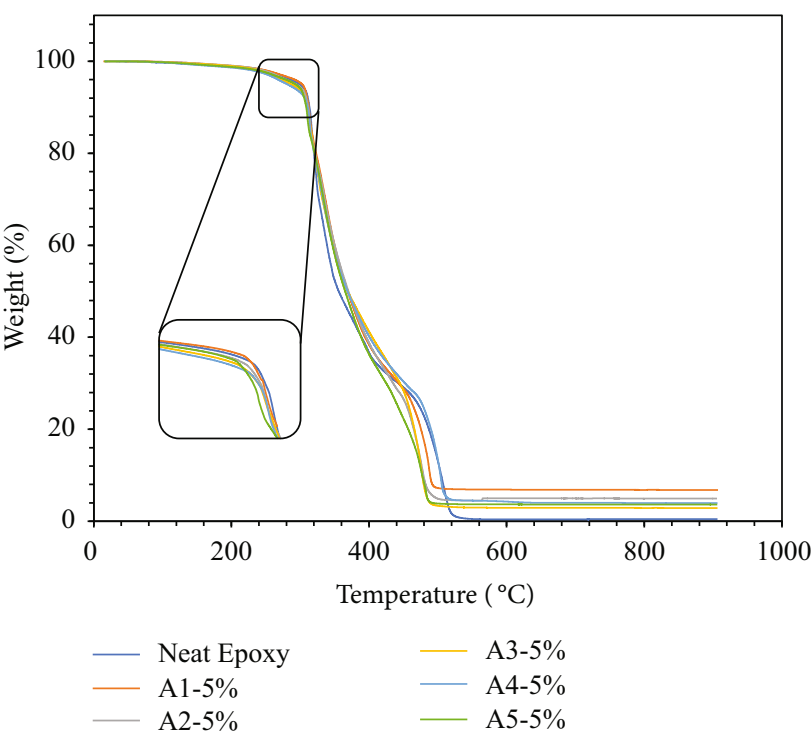

(b)

FIGURE 4: TGA of neat epoxy and epoxy/clay nanocomposites with (a) $1 \%$ wt and (b) $5 \%$ wt of clay loading.

$36,49-51]$. The obtained results showing that a small amount of unmodified clay (1\%wt) allowed the improvement of strain to failure and tensile strength of the nanocomposites indicated a good dispersion of the clays, in particular in the case of $A 5$. This effect could be attributed to the large interfacial interaction between the matrix and the clay, the aspect ratio of the dispersed clay particle, and the nanometer scale clay particle dimension. It is noteworthy that here an 
TABLE 2: Residue of neat epoxy and epoxy/clay nanocomposites after thermal treatment until $900^{\circ} \mathrm{C}$.

\begin{tabular}{|c|c|c|c|c|c|c|c|c|c|c|c|}
\hline Sample & Neat epoxy resin & $E A 1_{1 \%}$ & $E A 1_{5 \%}$ & $E A 2_{1 \%}$ & $E A 2_{5 \%}$ & $E A 3_{1 \%}$ & $E A 3_{5 \%}$ & $E A 4_{1 \%}$ & $E A 4_{5 \%}$ & $E A 5_{1 \%}$ & $E A 5_{5 \%}$ \\
\hline Onset of thermal degradation $\left({ }^{\circ} \mathrm{C}\right)$ & 319.36 & 315.24 & 314.25 & 314.19 & 313.85 & 315.13 & 315.44 & 316.60 & 315.01 & 325.24 & 310.80 \\
\hline Initial weight (mg) & 17.73 & 21.06 & 17.66 & 23.29 & 16.81 & 20.14 & 17.03 & 21.52 & 22.72 & 17.67 & 21.13 \\
\hline Residue (mg) & 0.076 & 0.275 & 1.200 & 0.349 & 0.826 & 0.073 & 0.491 & 0.131 & 0.903 & 0.773 & 0.771 \\
\hline Residue (\% wt) & 0.48 & 1.31 & 6.80 & 1.50 & 4.91 & 0.36 & 2.89 & 0.61 & 3.98 & 3.38 & 4.65 \\
\hline
\end{tabular}

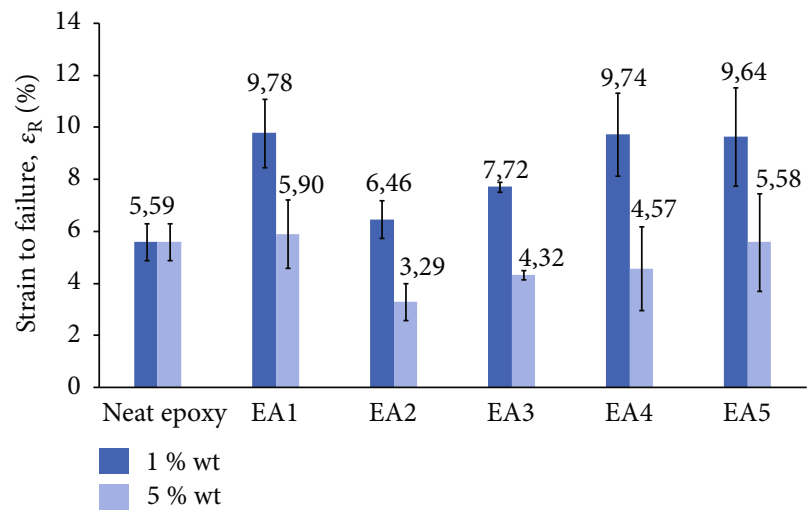

(a)

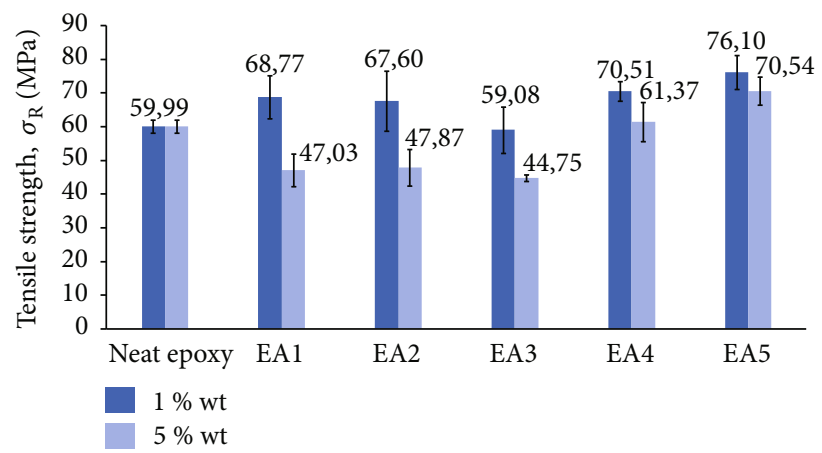

(b)

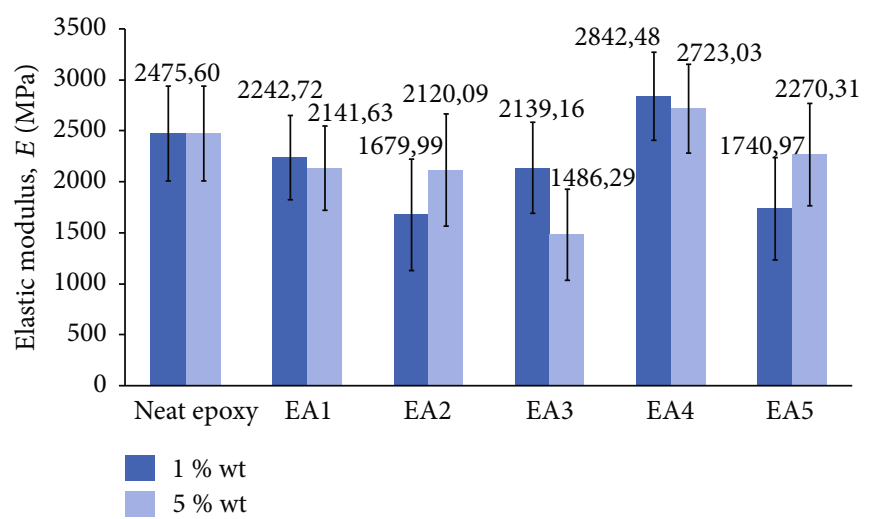

(c)

Figure 5: Strain to failure (a), tensile strength (b), and Young's modulus (c) of neat epoxy and epoxy/clay nanocomposites with $1 \%$ wt and 5\% wt loading of $A 1, A 2, A 3, A 4$, and $A 5$ clays.

improvement of mechanical properties was observed at a lower value $(1 \%$ wt) of clay content with respect to the amount often considered necessary for a reinforcement of the nanocomposite $(3 \%)[61,62]$. It should be noted that comparable results have been reported for the epoxy/clay nanocomposite bearing an interpenetrating PEO network, where the best mechanical properties have been obtained with $1 \%$ wt clay (MMT) content [63].

As evident from Figure 5(c), the addition of unmodified clays had a detrimental effect on the elastic modulus, $E$, except for $E A 4_{1 \%}$.

3.5. Fracture Tests. As far as fracture tests are concerned, 5 CT specimens were used for each material configuration and the results for $K_{\mathrm{IC}}$ in terms of average values are reported in Figure 6. It is noteworthy that, different from tensile properties, the mode I fracture toughness presented a monotonic increase with the filler content increase (except for the A5 nanoclay), in agreement with the behavior reported in the literature [64]. Based on the experimental results, the most effective toughening clay was $A 3$, which allowed the epoxy resin fracture toughness to be increased from $0.96 \mathrm{MPa} \mathrm{m}^{0.5}$ (neat polymer) to about 1.22 for filler content of $1 \%$ and up to about $1.35 \mathrm{MPam}^{0.5}$ with a weight fraction of $5 \%$ of nanoclays.

3.6. Point of Zero Charge $\left(p H_{p z c}\right)$. The point of zero charge is a very important characteristic that allows to determine the $\mathrm{pH}$ at which the material has net electrical neutrality. In Figure 7, the plots of $\Delta \mathrm{pH}\left(\mathrm{pH}_{0}-\mathrm{pH}_{\mathrm{f}}\right)$ vs. $\mathrm{pH}_{0}$ are reported. The point of zero charge for neat epoxy was found to be 6.2 and that of epoxy/clay nanocomposites prepared with $1 \%$ of $A 1\left(E A 1_{1 \%}\right)$, $A 4\left(E A 4_{1 \%}\right)$, and $A 5\left(E A 5_{1 \%}\right)$ were 6.9, 7, and 6.7, respectively, whereas those of $E A 2_{1 \%}$ and $E A 3_{1 \%}$ had approximately 


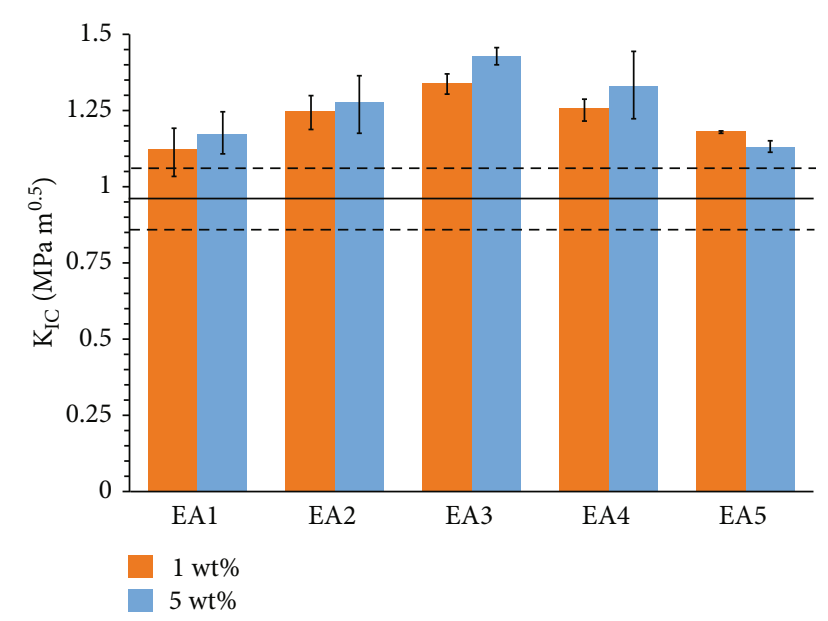

Figure 6: Effect of the nanomodification of the epoxy resin on the fracture toughness. The mean value and the scatter band of the values for neat epoxy is given by the black solid and dashed lines, respectively.

the same $\mathrm{pH}_{\mathrm{pzc}}$ of neat epoxy. By increasing the concentration of clay particles from 1 to $5 \% \mathrm{wt}$, the $\mathrm{pH}_{\mathrm{pzc}}$ remains in the same order with a variation of $\approx 0.1$ units. It was observed that $\mathrm{pH}_{\mathrm{pzc}}$ of neat epoxy was lower than that of EA4 nanocomposites, and it was higher than that of EA1 nanocomposites. This variation in $\mathrm{pH}_{\mathrm{pzc}}$ could be related to the difference in the surface functional groups of the materials, in particular $\mathrm{OH}$ and $\mathrm{NH}$ on the epoxy resin. They can interact in different ways and extent with the complex mixture of metals present in the raw clay materials, thus depending on their composition. It should be noted that in the case of EA4 composites, bearing a higher carbonate content, $\mathrm{pH}_{\mathrm{pzc}}$ resulted in an increase in comparison with the neat epoxy resin.

3.7. Antimicrobial Activity of Clays and Nanocomposites. The emergence of an increasing number of antibiotic-resistant strains of bacteria has significantly boosted the research for new antibacterial materials. In particular, some intriguing studies have been recently reported concerning natural clays [38-44]. As for natural clays A1-A5, the data concerning their activity against $E$. coli and $S$. aureus have been collected in Figure 8. We observed that all clays under investigation did not show bacteriostatic or biocidal activity against E. coli, while a biocidal activity corresponding to a reduction of $22 \%$ of units forming colonies was observed in the case of $A 1$ and $A 3$ and $24 \%$ for $A 2$ against $S$. aureus. The activity resulted in being lower (7\%) in the case of $A 4$, while for $A 5$, the reduction was significantly higher (42\%).

The antibacterial activity of the epoxy polymer loading natural clays has been established by measuring the growth inhibition of selected bacteria in comparison with the controls. The results have been collected in Table 3. The presence of clays $A 1, A 2$, and $A 3$ in the epoxy clay nanocomposites did not induce any bacteriostatic activity against $E$. coli either at $1 \%$ wt or $5 \%$ wt compared to neat epoxy resin; on the contrary, a moderate antibacterial activity could be observed against $S$. aureus in the case of $A 2$ and A3. EA4 showed an antibacterial activity against either $E$. coli or $S$. aureus depending on the clay amount: the killing percentage of $E A 4_{5 \%}$ against $S$. aureus was $99.88 \%$. The highest antibacterial activity against $E$. coli was observed for $E A 5_{1 \%}$ and $E A 5_{5 \%}$, whereas against $S$. aureus, $E A 4_{5 \%}, E A 5_{1 \%}$, and $E A 5_{5 \%}$ registered the highest effects (killing percentage of $E A 5_{5 \%}$ against E. coli and S. aureus raised up $99.86 \%$ and 99.99\%, respectively).

For nanocomposites loaded with $A 1, A 2$, and $A 3$, our hypothesis is that the presence of chlorite and a high amount of $\mathrm{Al}_{2} \mathrm{O}_{3}$ and $\mathrm{Na}_{2} \mathrm{O}$ could cause the antibacterial activity in particular against $S$. aureus, which has a much less complicated cell wall structure than Gram-negative bacteria and lower dimension than E. coli [65], thus being more sensible to biocidal systems (reported diameter of $S$. aureus 0.5 $1 \mu \mathrm{m}$; length of E. coli $1.5-2 \mu \mathrm{m})$. As for the biocidal activity of nanocomposites containing $A 4$ and $A 5$, it could be explained with the high content of calcium (for A4) and iron (for A5), in agreement with the data reported in the literature $[41,66]$. The occurrence of low-ordered iron mineral phases (goethite) in $A 5$ enhances the solubility of iron compared to silicates and crystalline oxides. The improvement of the activity of nanocomposites with respect to the free clays could be explained with the availability of a support for bacteria adhesion which could improve the contact with bactericidal clays and the surface. The EA5 surface had also the farthest $\mathrm{pH}$ value with respect to the nutrient broth (6.8), enhancing possible electrical interaction with the negative cell wall of bacteria, whereas for EA4, the nutrient medium sustained carbonate dissolution and then $\mathrm{Ca}, \mathrm{Mg}$ (possibly also $\mathrm{Fe}^{2+}$ ) solubilisation. The results are in agreement with some observations previously reported concerning nanocomposites exhibiting antimicrobial activity for which two mechanisms are proposed: activity of surfactant release from the clay and the action of the solid surface $[67,68]$.

It is noteworthy that the biocidal activity of the nanocomposites described here is comparable with the data reported for nanocomposites loading silver ions, which are the most used bactericidal agents $[69,70]$. As an example, $\mathrm{TiO}_{2} / \mathrm{Ag}^{+}$ exchanged montmorillonite in polyacrylic latex coatings produced an antibacterial effect at 1\% wt content [69], and a similar effect was reported for silver-embedded epoxy/clay nanocomposites at $2.5 \% \mathrm{wt}$ content [38].

\section{Conclusion}

The data described here showed that it is possible to obtain epoxy resin nanocomposites even when using suitable unmodified natural clays, if strongly milled and using exclusively the thinner fraction. TEM analysis indicated that partially intercalated systems could be achieved. The most intriguing results have been represented by the improvement of the mechanical properties in the presence of $1 \%$ wt of clay and of the onset temperature of thermal degradation in the case of $1 \%$ wt of $A 5$.

Furthermore, biocidal activity against $S$. aureus was observed for all the nanocomposites, and in the presence of $A 4$ and $A 5$, the antimicrobial action was evidenced also against $E$. coli even in the presence of a low amount of clays. 


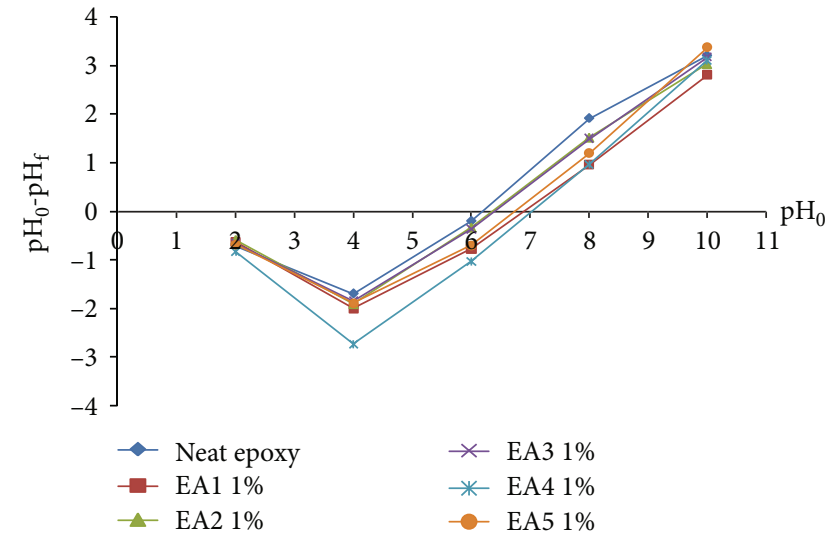

(a)

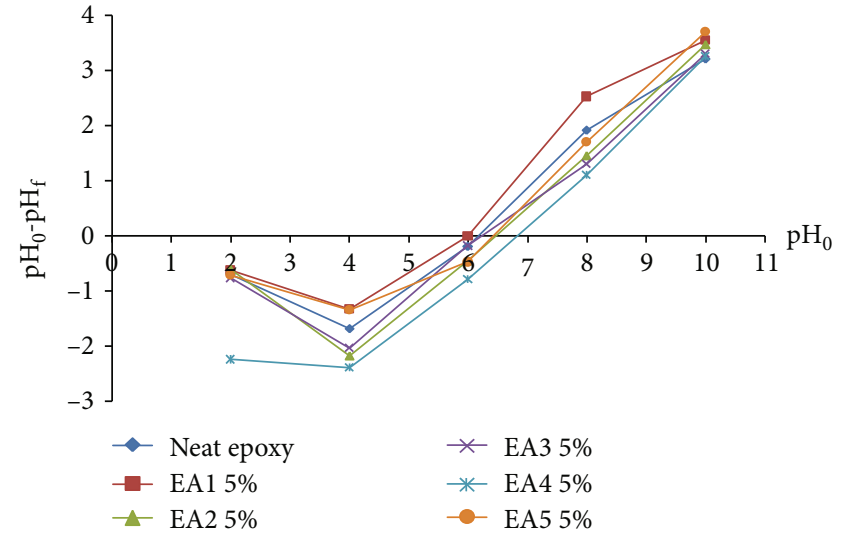

(b)

FIGURE 7: Determination of the point of zero charge of (a) the nanocomposites prepared with $1 \%$ and (b) the nanocomposites prepared with $5 \%$ of clay by the solid addition method.

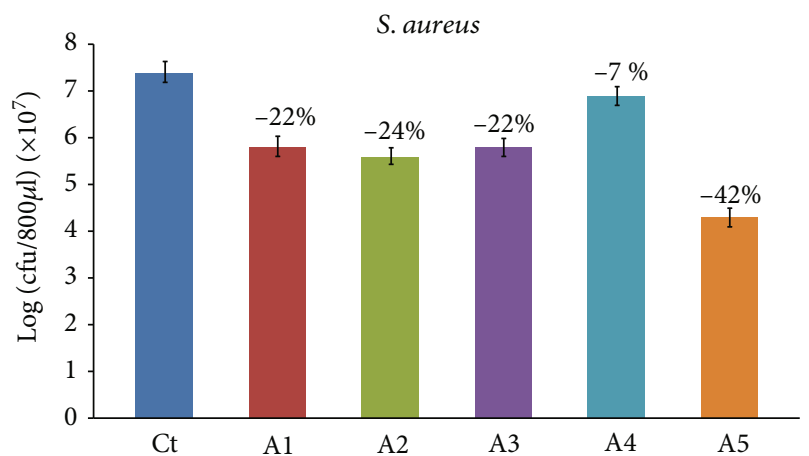

(a)

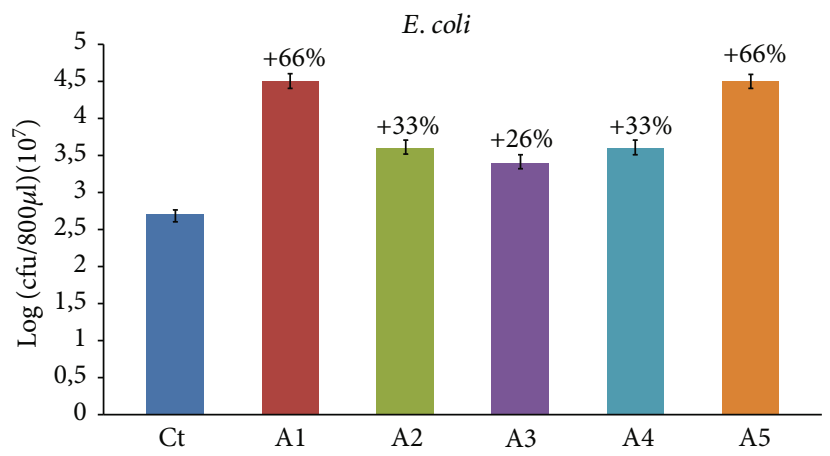

(b)

FIgURE 8: Biological activity of the natural clays A1-A5 against E. coli and S. aureus.

TABLe 3: Antibacterial activity of epoxy/clay nanocomposites against E. coli and S. aureus.

\begin{tabular}{|c|c|c|c|c|c|c|c|c|c|c|c|}
\hline \multirow{2}{*}{ Ech. } & \multirow{2}{*}{ Control } & \multicolumn{2}{|c|}{$E A 1$} & \multicolumn{2}{|c|}{$E A 2$} & \multicolumn{2}{|c|}{$E A 3$} & \multicolumn{2}{|c|}{$E A 4$} & \multicolumn{2}{|c|}{ EA5 } \\
\hline & & $1 \%$ & $5 \%$ & $1 \%$ & $5 \%$ & $1 \%$ & $5 \%$ & $1 \%$ & $5 \%$ & $1 \%$ & $5 \%$ \\
\hline \multicolumn{12}{|l|}{ E. coli } \\
\hline $\mathrm{cfu} / 50 \mu \mathrm{l}$ & $1.6 * 10^{5}$ & $5.5 * 10^{6}$ & $5.8 * 10^{6}$ & $1.5 * 10^{6}$ & $2 * 10^{7}$ & $1.8 * 10^{7}$ & $6.7 * 10^{6}$ & $1.9 * 10^{4}$ & $1.1 * 10^{4}$ & $<10$ & $2.24 * 10^{2}$ \\
\hline $\mathrm{cfu} / \mathrm{cm}^{2}$ & $4 * 10^{4}$ & $1.4 * 10^{6}$ & $1.5 * 10^{6}$ & $3.8 * 10^{5}$ & $5 * 10^{6}$ & $4.5 * 10^{6}$ & $1.7 * 10^{6}$ & $4.75 * 10^{3}$ & $2.7 * 10^{3}$ & $<10$ & 56 \\
\hline$\%$ kill & - & - & - & - & - & - & - & 88.12 & 93.12 & 99.99 & 99.86 \\
\hline \multicolumn{12}{|l|}{ S. aureus } \\
\hline $\mathrm{cfu} / 50 \mu \mathrm{l}$ & $1.9 * 10^{6}$ & $1.5 * 10^{6}$ & $105 * 10^{6}$ & $2.9 * 10^{5}$ & $7.3 * 10^{5}$ & $3.1 * 10^{5}$ & $3.1 * 10^{5}$ & $8.9 * 10^{5}$ & $2.28 * 10^{3}$ & $1.9 * 10^{2}$ & $1.9 * 10^{2}$ \\
\hline $\mathrm{cfu} / \mathrm{cm}^{2}$ & $4.8 * 10^{5}$ & $3.8 * 10^{5}$ & $3.8 * 10^{5}$ & $7.3 * 10^{4}$ & $1.8 * 10^{5}$ & $7.8 * 10^{4}$ & $7.8 * 10^{4}$ & $2.24 * 10^{5}$ & $5.7 * 10^{2}$ & 47.5 & 47.5 \\
\hline$\%$ kill & - & 20.83 & 20.83 & 84.79 & 62.5 & 83.75 & 83.75 & 87.78 & 99.88 & 99.99 & 99.99 \\
\hline
\end{tabular}

These results suggest further investigating the direct influence of the single components of the natural clays on the thermal, mechanical, and biocidal properties of the composite, in order to analyse the metal ion release kinetics and verify the antimicrobial effect at a longer term with the aim to modulate the characteristics of the nanocomposites for practical and industrial application, paying particular attention to the preparation of new antimicrobial materials, providing an alternative to surface modification or coating technologies. 


\section{Data Availability}

The FTIR spectra of the neat epoxy resin, and $E A 4_{5 \%}$ and $E A 5_{5 \%}$ nanocomposites together with the XRD spectra of $A 1, A 3$, and $A 5$ clays and the corresponding nanocomposites (5\% wt) used to support the findings of this study are included within the supplementary information file(s).

\section{Conflicts of Interest}

The authors declare no conflict of interest.

\section{Acknowledgments}

The authors thank Mr. Romeo Rabachin for the thermal and part of the mechanical determinations on nanocomposites. This work was prepared with the support of the University of Padova (DII and DTG) and of a grant within the Erasmus Mondus-al Idrisi II Project financed by the Erasmus Mundus programme of the European Union.

\section{Supplementary Materials}

The FTIR spectra of the nanocomposites resulted in being slightly modified with respect to the spectrum of the pristine epoxy resin (Figure SI 1 A: the strong absorptions of $v_{\text {CCaro- }}$ matic $v_{\mathrm{CCOC}}, v_{\mathrm{CN}}$, and $v_{\mathrm{COCethers}}$ and $v_{\mathrm{COC}}$ 年irane were present at $1508,1239,1104,1032$ and $827 \mathrm{~cm}^{-1}$, respectively) along with an increased broad band at $3392 \mathrm{~cm}^{-1}$ of the $\mathrm{OH}$ stretching of $\mathrm{Si}-\mathrm{OH}$ and $\mathrm{Al}-\mathrm{OH}$ and of the hydroxyl groups present in the epoxy matrix $[35,36]$. In the case of $E A 4_{5 \%}$, a small broadening of the signal at $1450 \mathrm{~cm}^{-1}$ was observed due to the presence of a strong and broad signal in $A 4$ at $1430 \mathrm{~cm}^{-1}$ of calcite (Figure SI 1 B). FTIR spectra of raw epoxy resin and of $E A 5_{5 \%}$ are quite similar to each other. In Figure SI 2, the XRD spectra of $A 1, A 3$, and $A 5$ and of the corresponding nanocomposites $E A 1_{5 \%}, E A 3_{5 \%}$, and $E A 5_{5 \%}$ are reported. The spectra exhibited the signals corresponding to the crystalline phases of the original clay. No clear evidence of the presence of intercalated systems could be observed, reasonably due to the use of raw clays, without previous pretreatment with organic components, and to the presence of a low amount of phillosilicates in the raw clays. (Supplementary Materials)

\section{References}

[1] D. R. Paul and L. M. Robeson, "Polymer nanotechnology: nanocomposites," Polymer, vol. 49, no. 15, pp. 3187-3204, 2008.

[2] A. A. Voevodin, J. P. O’Neill, and J. S. Zabinski, "Nanocomposite tribological coatings for aerospace applications," Surface and Coating Technology, vol. 116-119, pp. 36-45, 1999.

[3] J. M. Garcés, D. J. Moll, J. Bicerano, R. Fibiger, and D. G. McLeod, "Polymeric nanocomposites for automotive applications," Advanced Materials, vol. 12, no. 23, pp. 1835-1839, 2000.

[4] J. Markarian, "Automotive and packaging offer growth opportunities for nanocomposites," Plastics, Additives and Compounding, vol. 7, no. 6, pp. 18-21, 2005.
[5] T. Ebina, "Development of clay-based films," The Chemical Record, vol. 18, no. 7-8, pp. 1020-1032, 2018.

[6] R. K. Goyal, A. N. Tiwari, U. P. Mulik, and Y. S. Negi, "Dynamic mechanical properties of $\mathrm{Al}_{2} \mathrm{O}_{3}$ /poly(ether ether ketone) composites," Journal of Applied Polymer Science, vol. 104, no. 1, pp. 568-575, 2007.

[7] N. S. Hmeidat, J. W. Kemp, and B. G. Compton, "Highstrength epoxy nanocomposites for $3 \mathrm{D}$ printing," Composites Science and Technology, vol. 160, pp. 9-20, 2018.

[8] O. Zabihi, M. Ahmadi, S. Nikafshar, K. Chandrakumar Preyeswary, and M. Naebe, "A technical review on epoxy-clay nanocomposites: structure, properties, and their applications in fiber reinforced composites," Composites Part B: Engineering, vol. 135, pp. 1-24, 2018.

[9] G. G. Amatucci, N. Pereira, F. Badway et al., "Formation of lithium fluoride/metal nanocomposites for energy storage through solid state reduction of metal fluorides," Journal of Fluorine Chemistry, vol. 132, no. 12, pp. 1086-1094, 2011.

[10] H. Xu, S. W. Kuo, C. F. Huang, and F. C. Chang, "Poly(acetoxystyrene-co-isobutylstyryl POSS) nanocomposites: characterization and molecular interaction," Journal of Polymer Research, vol. 9, no. 4, pp. 239-244, 2002.

[11] M. Kawasumi, "The discovery of polymer-clay hybrids," Journal of Polymer Science Part A: Polymer Chemistry, vol. 42, no. 4, pp. 819-824, 2004.

[12] A. M. el Saeed, M. A. Abd El Fattah, and M. M. Dardir, "Synthesis and characterization of titanium oxide nanotubes and its performance in epoxy nanocomposite coating," Progress in Organic Coatings, vol. 78, pp. 83-89, 2015.

[13] P. D. Castrillo, D. Olmos, H. J. Sue, and J. González-benito, "Mechanical characterization and fractographic study of epoxy-kaolin polymer nanocomposites," Composite Structures, vol. 133, pp. 70-76, 2015.

[14] O. Becker and G. P. Simon, Polymer Nanocomposites, Y. W. May and Z. Z. Yu, Eds., CRC Press, 2006.

[15] S. Pavlidou and C. D. Papaspyrides, "A review on polymerlayered silicate nanocomposites," Progress in Polymer Science, vol. 33, no. 12, pp. 1119-1198, 2008.

[16] M. Ilsouk, M. Raihane, V. Castelvetro et al., "Highly thermostable and crystalline poly(butylene adipate) bionanocomposites prepared byin situpolycondensation with organically modified Moroccan beidellite clay," Polymer International, vol. 66, no. 6, pp. 939-949, 2017.

[17] B. K. G. Theng, Formation and Properties of Clay-Polymer Complexes, Elsevier, 1st edition, 1979.

[18] A. Ali, A. S. Mohammed, and N. Merah, "Tribological investigations of UHMWPE nanocomposites reinforced with three different organo-modified clays," Polymer Composites, vol. 39, no. 7, pp. 2224-2231, 2018.

[19] R. Sengupta, S. Chakraborty, S. Bandyopadhyay et al., "A short review on Rubber/Clay nanocomposites with emphasis on mechanical properties," Polymer Engineering and Science, vol. 47, pp. 21-25, 2007.

[20] J. M. Hutchinson, S. J. Montserrat, F. Roman, P. Cortes, and L. Campos, "Intercalation of epoxy resin in organically modified montmorillonite," Journal of Applied Polymer Science, vol. 102, no. 4, pp. 3751-3763, 2006.

[21] M. Bashar, P. Mertiny, and U. Sundararaj, "Effect of nanocomposite structures on fracture behavior of epoxy-clay nanocomposites prepared by different dispersion methods," Journal of Nanomaterials, vol. 2014, Article ID 312813, 12 pages, 2014. 
[22] K. Saitoh, K. Ohashi, T. Oyama et al., "Development of highperformance epoxy/clay nanocomposites by incorporating novel phosphonium modified montmorillonite," Journal of Applied Polymer Science, vol. 122, no. 1, pp. 666-675, 2011.

[23] Q. T. Nguyen and D. G. Baird, "Preparation of polymer-clay nanocomposites and their properties," Advances in Polymer Technology, vol. 25, no. 4, pp. 270-285, 2007.

[24] M. Tomic, B. Dunjic, M. S. Nikolic et al., "Dispersion efficiency of montmorillonites in epoxy nanocomposites using solution intercalation and direct mixing methods," Applied Clay Science, vol. 154, pp. 52-63, 2018.

[25] T. D. Ngo and M. T. Ton-That, "Wet process and exfoliation of clay in epoxy," Korean Journal of Chemical Engineering, vol. 33, no. 12, pp. 3550-3557, 2016.

[26] A. A. Azeez, K. Y. Rhee, S. J. Park, and D. Hui, "Epoxy clay nanocomposites - processing, properties and applications: A review," Composites Part B: Engineering, vol. 45, no. 1, pp. 308-320, 2013.

[27] A. Al-Maharma and P. Sendur, "Review of the main factors controlling the fracture toughness and impact strength properties of natural composites," Materials Research Express, vol. 6, no. 2, article 022001, 2019.

[28] Y. Zhang, D. Zhang, C. Qin, and J. Xu, "Physical and mechanical properties of dental nanocomposites composed of aliphatic epoxy resin and epoxidized aromatic hyperbranched polymers," Polymer Composites, vol. 30, no. 2, pp. 176-181, 2009.

[29] Z. R. Jia, Z. G. Gao, D. Lan, Y. H. Cheng, G. L. Wu, and H. Wu, "Effects of filler loading and surface modification on electrical and thermal properties of epoxy/montmorillonite composite," Chinese Physics B, vol. 27, no. 11, article 117806, 2018.

[30] D. Feldman, "Polymer nanocomposites in medicine," Journal of Macromolecular Science, Part A, vol. 53, no. 1, pp. 55-62, 2016.

[31] G. S. Martynkova and M. J. Valaskova, “Antimicrobial Nanocomposites Based on Natural Modified Materials: A Review of Carbons and Clays," Journal of Nanoscience and Nanotechnology, vol. 14, no. 1, pp. 673-693, 2014.

[32] A. Muñoz-Bonilla and M. Fernández-Garcia, "Polymeric materials with antimicrobial activity," Progress in Polymer Science, vol. 37, no. 2, pp. 281-339, 2012.

[33] A. Giannakas, M. Vlacha, C. Salmas et al., "Preparation, characterization, mechanical, barrier and antimicrobial properties of chitosan/PVOH/clay nanocomposites," Carbohydrate Polymers, vol. 140, pp. 408-415, 2016.

[34] G. Das, R. D. Kalita, P. Gogoi, A. K. Buragohain, and N. Karak, "Antibacterial activities of copper nanoparticle-decorated organically modified montmorillonite/epoxy nanocomposites," Applied Clay Science, vol. 90, pp. 18-26, 2014.

[35] A. Bartolozzi, R. Bertani, E. Burigo et al., "Multifunctional Cu2 +-montmorillonite/epoxy resin nanocomposites with antibacterial activity," Journal of Applied Polymer Science, vol. 134, no. 16, pp. 1-11, 2017.

[36] B. De, K. Gupta, M. Mandal, and N. Karak, "Biocide immobilized OMMT-carbon dot reduced $\mathrm{Cu}_{2} \mathrm{O}$ nanohybrid/hyperbranched epoxy nanocomposites: mechanical, thermal, antimicrobial and optical properties," Materials Science and Engineering: C, vol. 56, pp. 74-83, 2016.

[37] A. Mondrzyk, J. Fischer, and H. Ritter, "Antibacterial materials: structure-bioactivity relationship of epoxy-amine resins containing quaternary ammonium compounds covalently attached," Polymer International, vol. 63, no. 7, pp. 1192 1196, 2014.

[38] B. Roy, P. Bharali, B. K. Konwar, and N. Karak, "Silver-embedded modified hyperbranched epoxy/clay nanocomposites as antibacterial materials," Bioresource Technology, vol. 127, pp. 175-180, 2013.

[39] L. A. Savas and M. Hancer, "Montmorillonite reinforced polymer nanocomposite antibacterial film," Applied Clay Science, vol. 108, pp. 40-44, 2015.

[40] K. D. Morrison, J. C. Underwood, D. W. Metge, D. D. Eberl, and L. B. Williams, "Mineralogical variables that control the antibacterial effectiveness of a natural clay deposit," Environmental Geochemistry and Health, vol. 36, no. 4, pp. 613-631, 2014.

[41] K. D. Morrison, R. Misra, and L. B. Williams, "Unearthing the antibacterial mechanism of medicinal clay: a geochemical approach to combating antibiotic resistance," Scientific Reports, vol. 6, pp. 1-13, 2016.

[42] C. C. Otto and S. E. Haydel, "Exchangeable ions are responsible for the in vitro antibacterial properties of natural clay mixtures," PLoS One, vol. 8, no. 5, article e64068, 2013.

[43] L. B. Williams, D. W. Metge, D. D. Eberl et al., "What Makes a Natural Clay Antibacterial?," Environmental Science \& Technology, vol. 45, no. 8, pp. 3768-3773, 2011.

[44] L. B. Williams and S. E. Haydel, "Evaluation of the medicinal use of clay minerals as antibacterial agents," International Geology Review, vol. 52, no. 7-8, pp. 745-770, 2010.

[45] S. E. Haydel, C. M. Remenih, and L. B. Williams, "Broad-spectrum in vitro antibacterial activities of clay minerals against antibiotic-susceptible and antibiotic-resistant bacterial pathogens," Journal of Antimicrobial Chemotherapy, vol. 61, no. 2, pp. 353-361, 2008.

[46] M. Monsif, A. Zerouale, N. Idrissi Kandri Noureddine et al., "Chemical-physical and mineralogical characterization of ceramic raw materials from Moroccan northern regions: Intriguing resources for industrial applications," Applied Clay Science, vol. 182, article 105274, 2019.

[47] ISO 527-2, Plastics - Determination of tensile properties. Part 2: Test conditions for moulding and extrusion plastics, International Organization for Standardization, 2012.

[48] ASTM, D5045 Standard test methods for plane-strain fracture toughness and strain energy release rate of plastic materials, American Society for Testing and Materials, 1999.

[49] M. Quaresimin, R. Bertani, M. Zappalorto, A. Pontefisso, F. Simionato, and A. Bartolozzi, "Multifunctional polymer nanocomposites with enhanced mechanical and antimicrobial properties," Composites Part B: Engineering, vol. 80, pp. 108-115, 2015.

[50] M. Quaresimin, M. Salviato, and M. Zappalorto, "Fracture and interlaminar properties of clay-modified epoxies and their glass reinforced laminates," Engineering Fracture Mechanics, vol. 81, pp. 80-93, 2012.

[51] M. Zappalorto, M. Salviato, and M. Quaresimin, "Mixed mode (I + II) fracture toughness of polymer nanoclay nanocomposites," Engineering Fracture Mechanics, vol. 111, pp. 50-64, 2013.

[52] A. Kumar, B. Prasad, and I. M. Mishra, "Adsorptive removal of acrylonitrile by commercial grade activated carbon: Kinetics, equilibrium and thermodynamics," Journal of Hazardous Materials, vol. 152, no. 2, pp. 589-600, 2008. 
[53] ISO 22196, Plastics - Measurement of antibacterial activity on plastics surfaces, International Organization for Standardization, 2011.

[54] OECD, "Guidance document for quantitative method for evaluating antibacterial activity of porous and non-porous antibacterial treated materials," in Series on Testing and Assessment No.202, Series on Biocides No. 8, Organisation de coopération et de développement économiques, 2014.

[55] ASTM, "E2149-01 standard test method for determining the antimicrobial activity of immobilized antimicrobial agents under dynamic contact conditions," in American Society for Testing and Materials, 2010.

[56] M. Monsif, S. Rossignol, F. Allali et al., "The implementation of geopolymers materials from moroccan clay, within the framework of the valorizationof the local natural resources," Journal of Materials and Environmental Sciences, vol. 8, no. 8, pp. 2704-2721, 2017.

[57] S. O. Ilyin, T. V. Brantseva, I. Y. Gorbunova, S. V. Antonov, Y. M. Korolev, and M. L. Kerber, "Epoxy reinforcement with silicate particles: Rheological and adhesive properties - Part I: Characterization of composites with natural and organically modified montmorillonites," International Journal of Adhesion and Adhesives, vol. 61, pp. 127-136, 2015.

[58] G. Guzel, O. Sivrikaya, and H. Deveci, "The use of colemanite and ulexite as novel fillers in epoxy composites: Influences on thermal and physico-mechanical properties," Composites Part B: Engineering, vol. 100, pp. 1-9, 2016.

[59] T. Liu, W. C. Tjiu, Y. Tong, C. He, S. S. Goh, and T. S. Chung, "Morphology and fracture behavior of intercalated epoxy/clay nanocomposites," Journal of Applied Polymer Science, vol. 94, no. 3, pp. 1236-1244, 2004.

[60] M. Quaresimin, K. Schulte, M. Zappalorto, and S. Chandrasekaran, "Toughening mechanisms in polymer nanocomposites: From experiments to modelling," Composites Science and Technology, vol. 123, pp. 187-204, 2016.

[61] D. Rosu, C. D. Varganici, L. Rosu, and O. M. Mocamu, Eds., Thermal degradation of Polymer Blends, Composites and Nanocomposites, Springer, 2015.

[62] A. K. Mohapatra, S. Mohanty, and S. K. Nayak, "Study of thermo-mechanical and morphological behaviour of biodegradable PLA/PBAT/Layered silicate blend nanocomposites," Journal of Polymers and the Environment, vol. 22, no. 3, pp. 398-408, 2014.

[63] M. Wang, X. Fan, W. Thitsartarn, and C. He, "Rheological and mechanical properties of epoxy/clay nanocomposites with enhanced tensile and fracture toughnesses," Polymer, vol. 58, pp. 43-52, 2015.

[64] H. Y. Liu, G. T. Wang, Y. W. Mai, and Y. Zeng, "On fracture toughness of nano-particle modified epoxy," Composites Part B: Engineering, vol. 42, no. 8, pp. 2170-2175, 2011.

[65] S. Hsu, H. J. Tseng, H. S. Hung et al., "Antimicrobial activities and cellular responses to natural silicate clays and derivatives modified by cationic alkylamine salts," ACS Applied Materials \& Interfaces, vol. 1, no. 11, pp. 2556-2564, 2009.

[66] T. Şişmanoğlu, S. Karakuş, Ö. Birer et al., "Preparation and characterization of antibacterial Senegalia (Acacia) senega1/iron-silica bio-nanocomposites," Applied Surface Science, vol. 354, pp. 250-255, 2015.
[67] R. Nigmatullin, F. Gao, and V. Konovalova, "Polymer-layered silicate nanocomposites in The design of antimicrobial materials," Journal of Materials Science, vol. 43, no. 17, pp. 5728-5733, 2008.

[68] H. F. Giraldo Mejia, L. Yohai, A. Pedetta, K. Herrera Seitz, R. A. Procaccini, and S. A. Pellice, "Epoxy-silica/clay nanocomposite for silver-based antibacterial thin coatings: synthesis and structural characterization," Journal of Colloid and Interface Science, vol. 508, pp. 332-341, 2017.

[69] G. Carja, Y. Kameshima, A. Nakajima, C. Dranca, and K. Okada, "Nanosized silver-anionic clay matrix as nanostructured ensembles with antimicrobial activity," International Journal of Antimicrobial Agents, vol. 34, no. 6, pp. 534-539, 2009.

[70] A. Olad, R. Nosrati, H. Najjari, and K. Nofouzi, "Preparation and investigation of hydrophilic, photocatalytic, and antibacterial polyacrylic latex coating containing nanostructured $\mathrm{TiO}_{2} / \mathrm{Ag}^{+}$-exchanged-montmorillonite composite material," Applied Clay Science, vol. 123, pp. 156-165, 2016. 


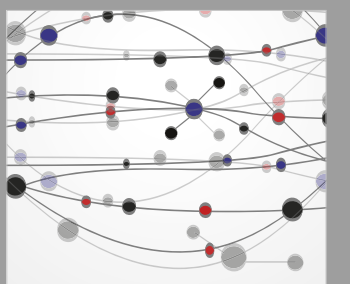

The Scientific World Journal
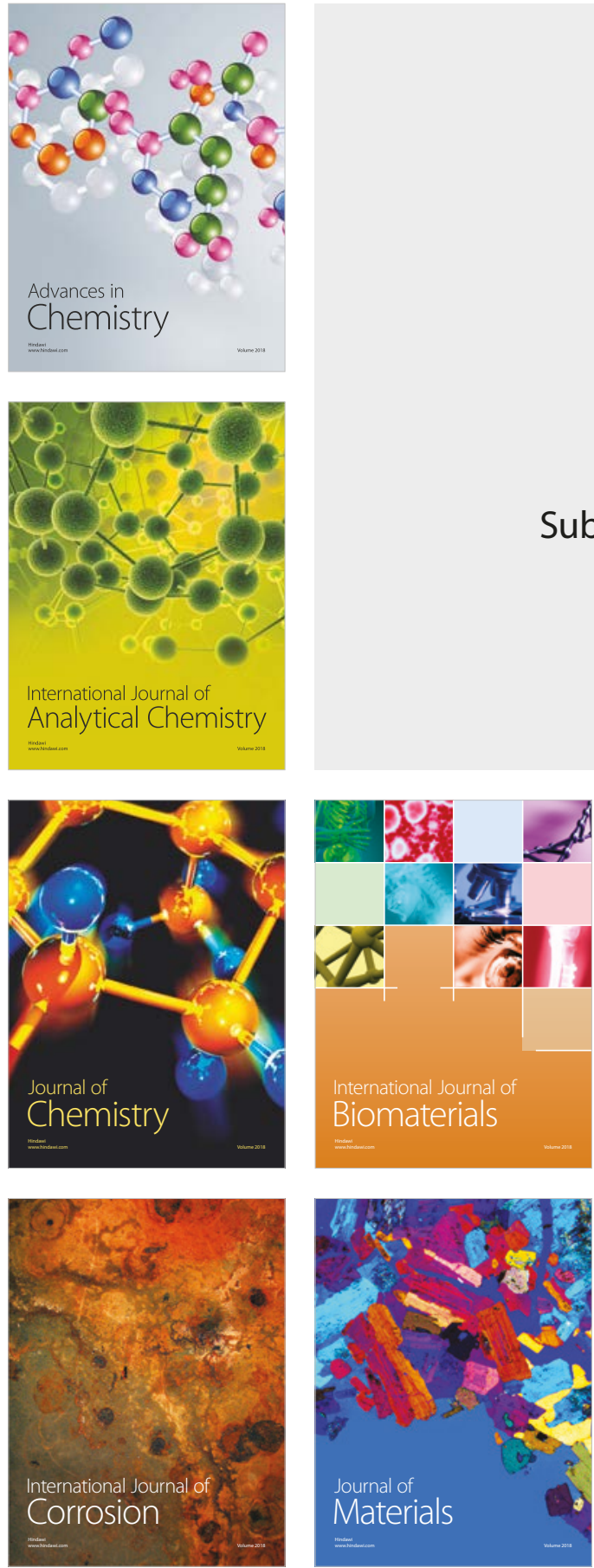

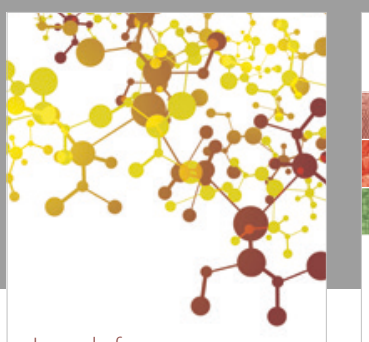

Journal of

Applied Chemistry
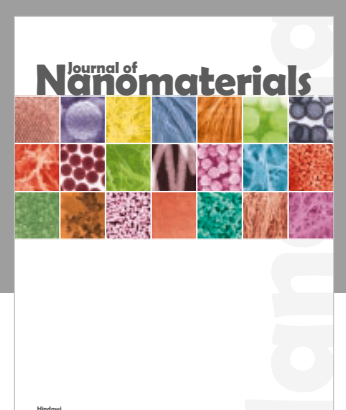

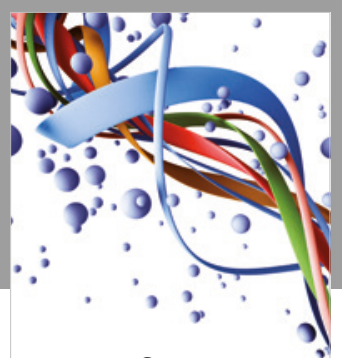

Scientifica

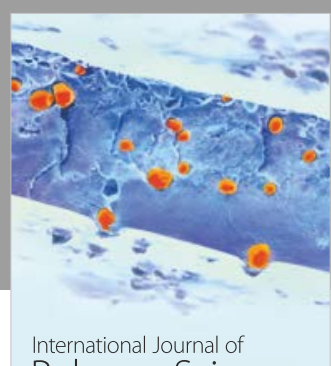

Polymer Science

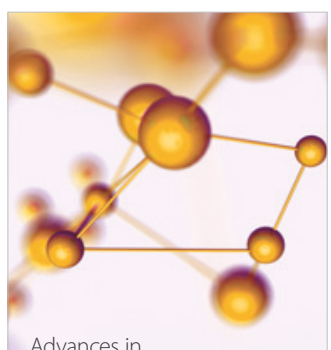

Physical Chemistry
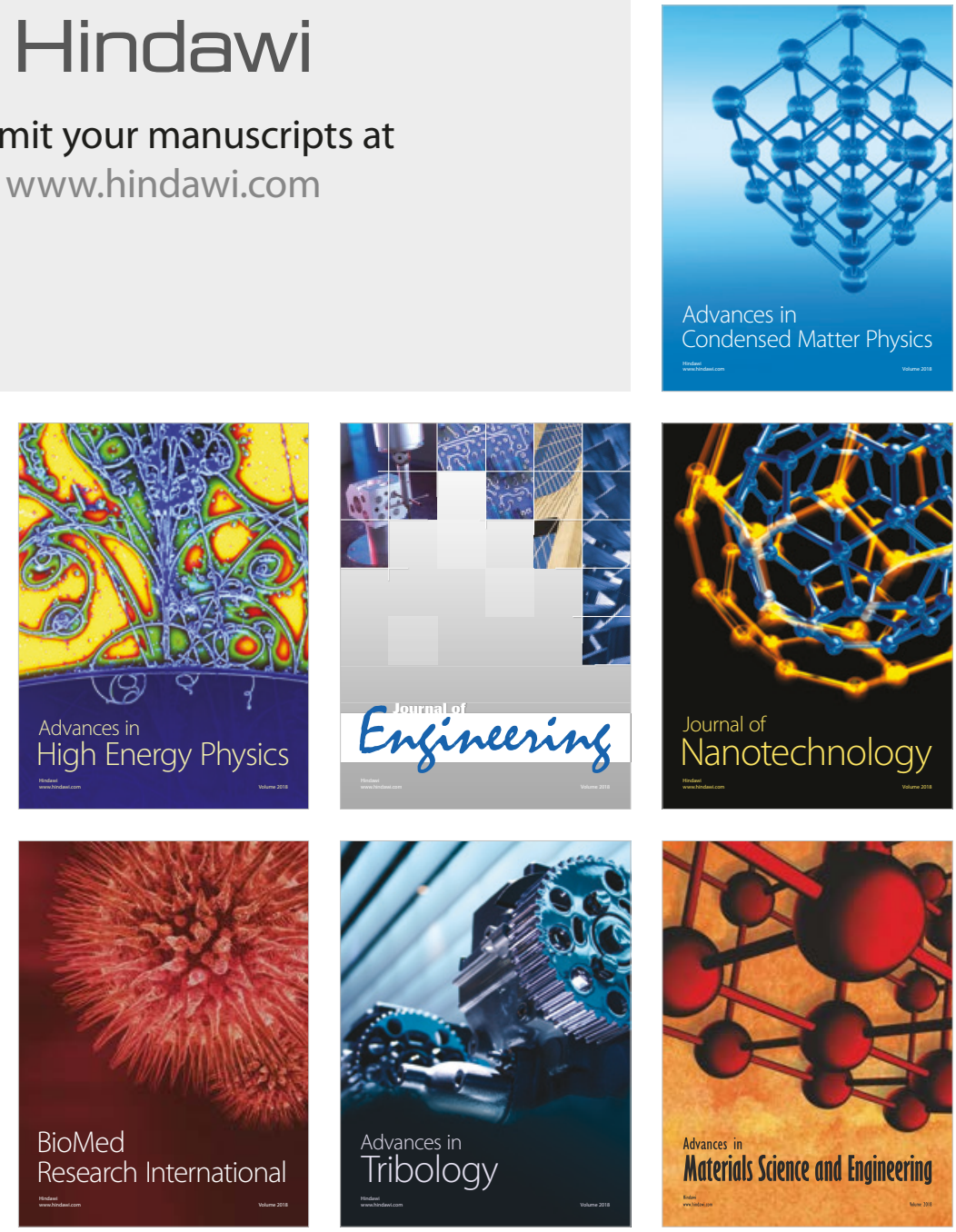